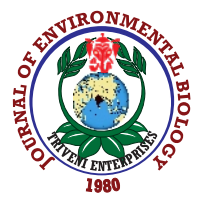

\title{
Energy use pattern of diversified cropping systems under different nutrient and crop residue management practices in Eastern Indo-Gangetic plain
}

\author{
M. Kumar'* S. Mitra ${ }^{2}$, A. Bera ${ }^{3}$ and M.R. Naik ${ }^{4}$ \\ 'Department of Agronomy, Dr. Rajendra Prasad Central Agricultural University, Samastipur-848 125, India \\ ${ }^{2}$ All India Network project on Jute and allied fibres, ICAR-Central Research Institute for Jute and allied Fibre crops, Barrackpore-700 120, India \\ ${ }^{3}$ Crop improvement Division, ICAR-Central Research Institute for Jute and allied Fibre crops, Barrackpore-700 120, India \\ ${ }^{4}$ Crop production division, ICAR-Central Research Institute for Jute and allied Fibre crops, Barrackpore-700 120, India \\ *Corresponding Author Email : mukesh.agro@gmail.com
}

Received: 06.04.2020

Revised: 21.07 .2020

Accepted: 14.12 .2020

\begin{abstract}
Aim: Assessment of energy input output relationship, greenhouse gases emission and carbon footprint of diversified jute-rice cropping systems under different nutrients and crop residue management practices.

Methodology: The inventory was prepared for all inputs required for crop cultivation and outputs of crops in cropping systems. These inputs and outputs were converted into energy by multiplying with energy equivalent coefficient and $\mathrm{CO}_{2}$ emission coefficient following standard procedure.

Results: Jute-rice-baby corn cropping system recorded significantly higher net energy (324 GJ ha ${ }^{-1}$ ) and energy use efficiency (8.02). Among different nutrient and crop management (NCRM) practices, significantly higher energy output (336.9 $\mathrm{GJ} \mathrm{ha}^{-1}$ ) and net energy (291.4 GJ ha ${ }^{-1}$ ) recorded 100\% NPK with crop residue. The highest carbon footprint recorded with rice-rice ( 0.44 $\mathrm{kg} \mathrm{COe} \mathrm{kg}^{-1}$ economic yield) and the lowestwith jute-rice-pea ( 0.29 $\mathrm{kg} \mathrm{CO} \mathrm{kg}^{-1}$ economic yield) cropping system. Among different NCRM practices, higher carbon footprint was $\left(0.38 \mathrm{~kg} \mathrm{COe} \mathrm{kg}^{-1}\right.$ economic yield) recorded with $100 \%$ NPK with crop residue.

Interpretation: The energy efficient and low input required cropping systems which include legume crops like garden pea and mungbean should be considered for cultivation for diversifying the existing rice-rice cropping system in Eastern India.

Key words: Carbon footprint, Crop residue, Energy, Greenhouse gases, Jute, Rice

To find out energy efficient and lower carbon footprint of different cropping systems under nutrient and crop residue management practices

Five cropping systems grown with different combination of NPK and crop residue

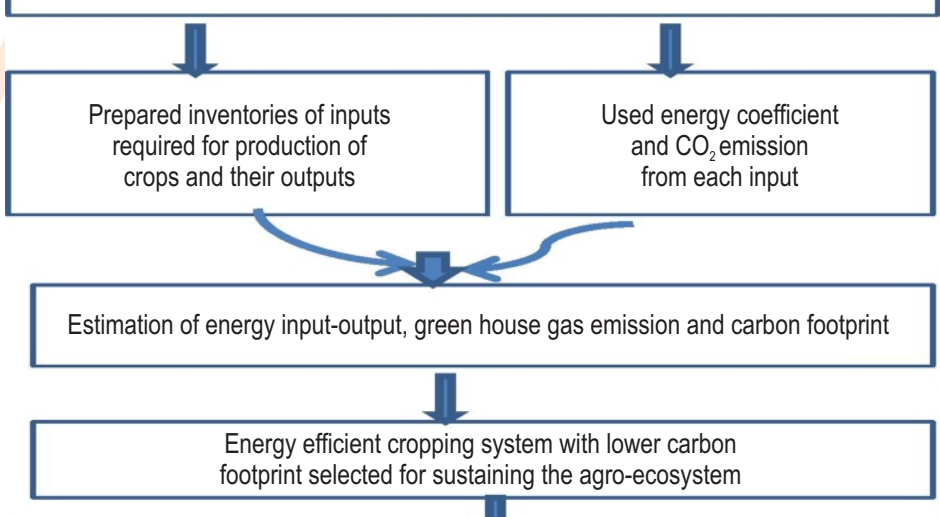

Jute-rice-garden pea and jute-rice-baby corn under $75 \%$ NPK with crop residue were the energy efficient and low carbon footprint cropping systems
\end{abstract}

How to cite : Kumar, M., S. Mitra, A. Bera and M.R. Naik: Energy use pattern of diversified cropping systems under different nutrient and crop residue management practices in Eastern Indo-Gangetic plain. J. Environ. Biol., 42, 1053-1061(2021). 


\section{Introduction}

The Eastern Indo-Gangetic plain comprise of Eastern Uttar Pradesh, Bihar and West Bengal is a predominant rice growing area. However, jute is grown as a cash crop in summer season (April-July) prior to kharif rice in this region (Mahaparta et al., 2012; Kumar et al., 2014). This jute-rice cropping systems followed by short duration crops viz., rapeseed, garden pea and potato in rabi season. Although, crop intensification and/or diversification has resulted in higher production per unit area per unit time lead to higher nutrient removal from soil and affect soil fertility (Biswas et al., 2006). The sustainability of jute-rice based system is a major challenge of this region due to imbalanced and increased use of inorganic fertilizer leading to decrease in factor productivity and deterioration of soil fertility (Timsina and Cornor, 2001). Substitution of inorganic fertilizers with renewable source of nutrient like manures, compost and crop residues not only help maintain the soil health but also reduced the burden of non-renewable source of energy input and emission green house gases from production site.

The practice of using crop residues in the soil considerably influences organic matter as well as carbon sequestration and thereby helps in maintaining soil organic carbon pool (Lal, 2004). But, addition of fresh organic materials is are not always eco-friendly due to high $\mathrm{C}: \mathrm{N}$ ratio and responsible for emission of more carbon dioxide during decomposition in the environment as compared to FYM or other compost organic manures (Ahmad, 2007; Li et al., 2012). One of the promising strategies for mitigating GHG emissions from farming is to adopt diversified cropping systems where cereal, oilseed, and pulses crops are arranged in a well defined crop rotation system (Singh et al., 2016). Such systems have been shown to increase energy use efficiency (Zentner et al., 2004, Singh and Ahlawat, 2015), decrease pest infestation (Krupinsky et al., 2002), improve water use efficiency (Miller et al., 2003) and increase net productivity of crops (Tanaka et al., 2007). There is a growing interest in reducing the carbon footprint of agricultural products, i.e. the total GHG emission associated with the amount of grain produced (Williams and Wikstrom, 2011). There are many crop management practices such as growing crop species having low carbon footprint, diversification of cropping systems, using biological nitrogen fixation crops, improving nutrient use efficiency of crop and crop residue management known to reduce the carbon footprint of crop production (Gan et al., 2011).

The methodology for GHG evaluation is easy where all the inputs required for crop production needs to be converted to one unit, such as the kilograms $(\mathrm{kg})$ of $\mathrm{CO}_{2}$ equivalent $\left(\mathrm{CO}_{2} \mathrm{e}\right)(\mathrm{Lal}$, 2004; Singh et al., 2016 ). Energy inputs and outputs are also important factors which affect the energy efficiency and environmental impact of crop production. The magnitude of input and output energy and consequently the energy efficiency of agricultural system varies considerably with farm location (weather, soil type), crop rotations use of fertilizers, etc. (Rathke et al., 2007). Among different agro-techniques for crop production, tillage and fertilizers are the fossil fuel energy consumers and contributes about $30 \%$ of total energy use in crop production (Singh et al., 2008) and in turn increases GHG emissions (Soni et al., 2013). According to Janzen et al. (2003) a large portion of emission is related to input of fertilizers, manures, plant litter, besides various biological and anthropogenic processes of the nutrients dynamics in soil. Chaudhary et al. (2009) reported reduction in energy efficiency due to energy inputs increasing faster than energy outputs. The efficiency of energy use can be increased by reducing inputs such as reducing the amount of fertilizer and tillage operations, or by increasing outputs such as crop yield (Singh et al., 2008; Singh et al., 2019). Several studies have evaluated energy balance and greenhouse gas emission in different cropping systems but there is limited information about cropping systems in combination with fertilizers and crop residue management practices in jute based cropping system. Hence, this study was carried out to determine energy used, $\mathrm{CO}_{2}$ e emissions and carbon footprint of diversified jute-rice based cropping systems under nutrients and crop residues management practices.

\section{Materials and Methods}

Experimental design and treatments: A field experiment was conducted at Central Research Institute for Jute and Allied Fibre Barrackpore, Kolkata, India. The soil was loamy with $\mathrm{pH}$ 7.1, bulk density $1.33 \mathrm{Mgm}^{-3}$ and cation exchange capacity $17.2 \mathrm{cmol}(\mathrm{p}+)$ $\mathrm{kg}^{-1}$. The experiment was laid out in split-plot design with five cropping systems viz., rice-rice (R-R), jute-rice-wheat (J-R-W), jute-rice-baby corn (J-R-Bc), jute-rice-garden pea (J-R-Gp), juterice-mustard-mungbean (J-R-M-Mu) in main plot and it was superimposed with four nutrients and crop residue management (NCRM) practices viz. 75\% recommended doses of fertilizers (RDF) without $\left(F_{1} R_{0}\right)$ and with $\left(F_{1} R_{1}\right)$ crop residue (rice, wheat and baby corn @ 4 mg ha ${ }^{-1}$; garden pea and mungbean@ 2 mg ha $^{-1}$ with their respective cropping sequence) and $100 \%$ RDF without $\left(F_{2} R_{0}\right)$ and with $\left(F_{2} R_{1}\right)$ crop residues. All these treatments were replicated thrice. Crops were cultivated following standard package and practices, except for the treatments applied.

Energy analysis: To study energy inputs and outputs of individual cropping systems, a complete inventory of all crop inputs (fertilizers, seeds, plant protection chemicals, fuel, human labour and machinery power) and outputs of both main and by-products was prepared. The energy value of each cropping system was determined based on energy inputs and energy production for individual crops in the system. Inputs and outputs were converted from physical to energy unit measures through published conversion coefficients (Mittal and Dhawan, 1988; Devsenapathy et al., 2009). Crop residue was not included in input energy because crop residue as output was 12.5 $\mathrm{MJ} \mathrm{kg}^{-1}$ energy equivalent but there was no information about energy equivalent residue as input. Therefore, many researchers (Moreno et al., 2011; Pratibha et al., 2015; Lal et al., 2019) did not use crop residue as input source while calculating the input energy. 
Estimation of greenhouse gas emissions: The effect of different diversified cropping system and nutrient and crop residue incorporation practices were assessed by calculating the Global warming potential (GWP). GWP is the total set of GHG emissions $\left(\mathrm{CO}_{2}, \mathrm{~N}_{2} \mathrm{O}\right.$ and $\left.\mathrm{CH}_{4}\right)$ produced directly or indirectly in crop production and was converted into $\mathrm{CO}_{2}$ equivalent $\left(\mathrm{CO}_{2} \mathrm{e}\right)$ using global warming potential equivalent factors of 1,21 and 310 for $\mathrm{CO}_{2}, \mathrm{CH}_{4}$ and $\mathrm{N}_{2} \mathrm{O}$, respectively, (IPCC, 2006). The amount of GHG emissions in terms of $\mathrm{CO}_{2}$ e was estimated by multiplying the input (diesel fuel, chemical fertilizer and pesticide) with its corresponding emission coefficient. The emission coefficients used in the study as per Lal, (2004) and West and Marland, (2002). Besides $\mathrm{CO}_{2}$ e emission from farm operations in crop production, direct and indirect $\mathrm{N}_{2} \mathrm{O}$ emissions from synthetic fertilizer application and $\mathrm{N}_{2} \mathrm{O}$ released during decomposition of crop residues left in the soil were also estimated by IPCC methodology (IPCC, 2006). Direct (emission factor) and indirect $\mathrm{N}_{2} \mathrm{O}$ emission (fraction of leaching and volatilization) was calculated as per Bhatia et al. (2004).

Carbon budgeting: Total carbon input was calculated by summing up all input used in crop production after converting it into carbon equivalent. Total carbon output was calculated by multiplying total dry biomass (grain+ straw+root) yield with factor 0.4 (Lal, 2004). Carbon sustainability index (CSI) was calculated by dividing the carbon output $\left(\mathrm{kg}^{\mathrm{C}} \mathrm{Ceha} \mathrm{C}^{-1}\right)$ by carbon input ( $\mathrm{kg}$ Ceha $\left.{ }^{-1}\right)$. The carbon footprint was calculated by dividing total carbon emission ( $\left.\mathrm{kg} \mathrm{Ceh}^{-1}\right)$ by economic yield $\left(\mathrm{kg} \mathrm{ha}^{-1}\right)$ of a crop as per methodology given by Ma et al. (2012)

Statistical analysis: Biomass yield, economic yield and all parameters of energy and carbon output were analyzed using ANOVA for a split-plot design using SPSS16 software (IBM Inc). The assumptions of ANOVA were satisfied for all parameters. Tukey's studentized range test (HSD) used as post hoc while doing multiple comparisons for means for main plot, subplottreatments and interaction between main plot and sub-plot treatments at significance level $P<0.05$.

\section{Results and Discussion}

Total biomass (economic yield+straw/stalk+root) production of different crops as well as cropping systems varied under nutrients and crop residue management practices (Fig.1). Higher total biomass was recorded with J-R-Bc (35 Mg ha-1) followed by J-R-W (33 Mg ha ${ }^{-1}$ ) cropping system. Total biomass production of different crops and cropping systems differed because of their genetic potential and management practices. Rice, wheat and baby corn had higher capacity to produce total biomass compared to garden pea, mustard and mungbean crops. Among nutrients and crop residue management practices, $F_{2} R_{1}$ recorded comparatively higher total system biomass than others. Biomass production under NCRM practices recorded higher because of proper supply of nutrients to all crops in system that favours plant growth and development (Parihar et al., 2017). It was also observed that biomass production with $75 \%$ RDF with crop residue $\left(F_{1} R_{1}\right)$ and 100\% RDF without crop residue $\left(F_{2} R_{0}\right)$ treatments was statistically at par. The results indicate that equal biomass of cropping systems can be produced when $25 \%$ of nutrients (NPK) requirement of cropping systems is substituted by crop residues and in this way the burden on inorganic fertilizers and fossil fuel consumption in agriculture system (Choudhary et al., 2009) can be reduced. System productivity varied among different cropping systems and NCRM. The highest productivity $\left(14.5 \mathrm{Mg} \mathrm{ha}^{-1}\right)$ was found in J-R-Bc cropping system followed by JR-Gp (9.41 Mg ha $\left.{ }^{-1}\right)$. NCRM practices did not significantly affect the system productivity but higher productivity $\left(10.4 \mathrm{Mg} \mathrm{ha}^{-1}\right)$ was found under $F_{2} R_{1}$ practice. The system productivity of J-R-Bc cropping system recorded the highest followed by J-R-Gp system. As system productivity is a function of crop yield and market price of products, higher value of crop product with higher yield recorded higher system productivity (Kumar et al., 2014). The difference in system productivity is due to variation in yield of different crops due to variable nutrients management practices and price of product/outputs of different crops in cropping systems.

The highest energy input (EI) was recorded in J-R-W (47.37 GJ ha ${ }^{-1}$ ) whereas the lowest (38.79 GJ ha') in double R-R cropping system. The J-R-Gp triple cropping and J-R-M-Mu, quadruple cropping recorded $14 \%$ and $6 \%$ lower El, respectively, compared to J-R-W cropping system. Energy requirements for cultivation of crops in cropping systems varied due to difference in the requirement of inputs for cultivation of crops and El was calculated on the basis of input requirements and energy coefficient. The variation in El among different cropping systems like fertilizers, irrigation, tillage operation human labour varied for various crops in cropping systems. The J-R-M-Mu, quadruple cropping required less El than J-R-W triple cropping because in previous cropping mustard $(\mathrm{M})$ and mungbean $(\mathrm{Mu})$ were sown on no tillage. No tillage sowing required less energy than conventional tillage only because it required less or almost no energy in tillage operation (Singh et al., 2008; Pratibha et al., 2015). The El of different field operations also varied with different cropping systems (Fig. 2). Fertilizer application shared maximum (33.9-42.3\%) of total energy input among all farm operations, followed by field preparation (16.9-25.5\%) and irrigation (15.7$22.1 \%$ ) irrespective of cropping system. Among different cropping systems, fertilizers application shared $42.3 \%$ of El inJ-R-BC system and minimum $33.9 \%$ in J-R-Gp cropping system.

The share of fertilizers application of total El in remaining other cropping systems were in order: J-R-M-Mu (38\%)> JRW $(37.9 \%)>\operatorname{RR}(34.6 \%)$. The minimum share of fertilizer input in J-RGp cropping system was mainly due to less amount of nitrogenous fertilizer required by garden pea crop. Garden pea is leguminous crop and it fulfills its nitrogen demand by fixing atmospheric nitrogen which significantly decreased the use of synthetic nitrogen fertilizer. Irrigation recorded the highest shared $(22.1 \%)$ of El in R-R system, followed by J-R-M-Mu (18.7\%), nevertheless, R$R$ was double cropping system. It's because rice required more quantity $(1500-2500 \mathrm{~mm})$ of water to complete its life cycle and 


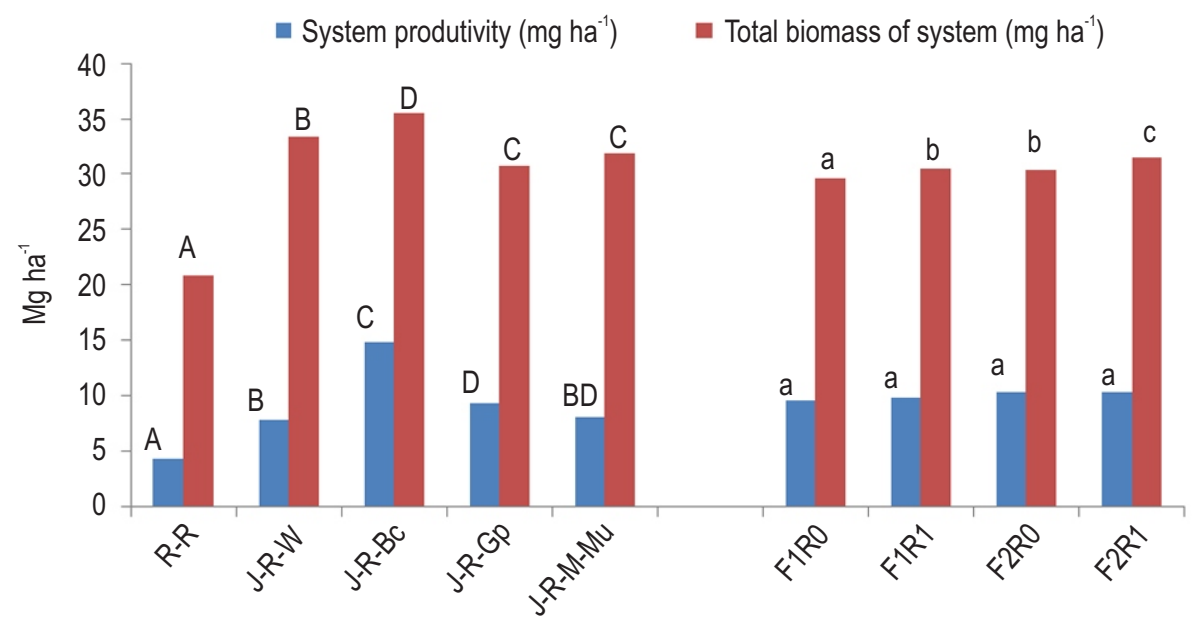

Fig. 1: System productivity and total biomass of the cropping system ( economic+ straw + root dry biomass) under different cropping system and nutrient and residue management practices. (J-Jute, R-Rice, W-wheat, Gp-Garden pea, Bc-Baby corn; M-Mustard, Mu-Mungbean ; F1-75\% NPK; F2-100\% NPK; R0-No residue; R1-residue incorporation;) Means followed by similar letters (Capital letter for main plot and small for sub plot comparison) within a column are not significantly different at $P<0.05$ according to Tukey's HSD test.).

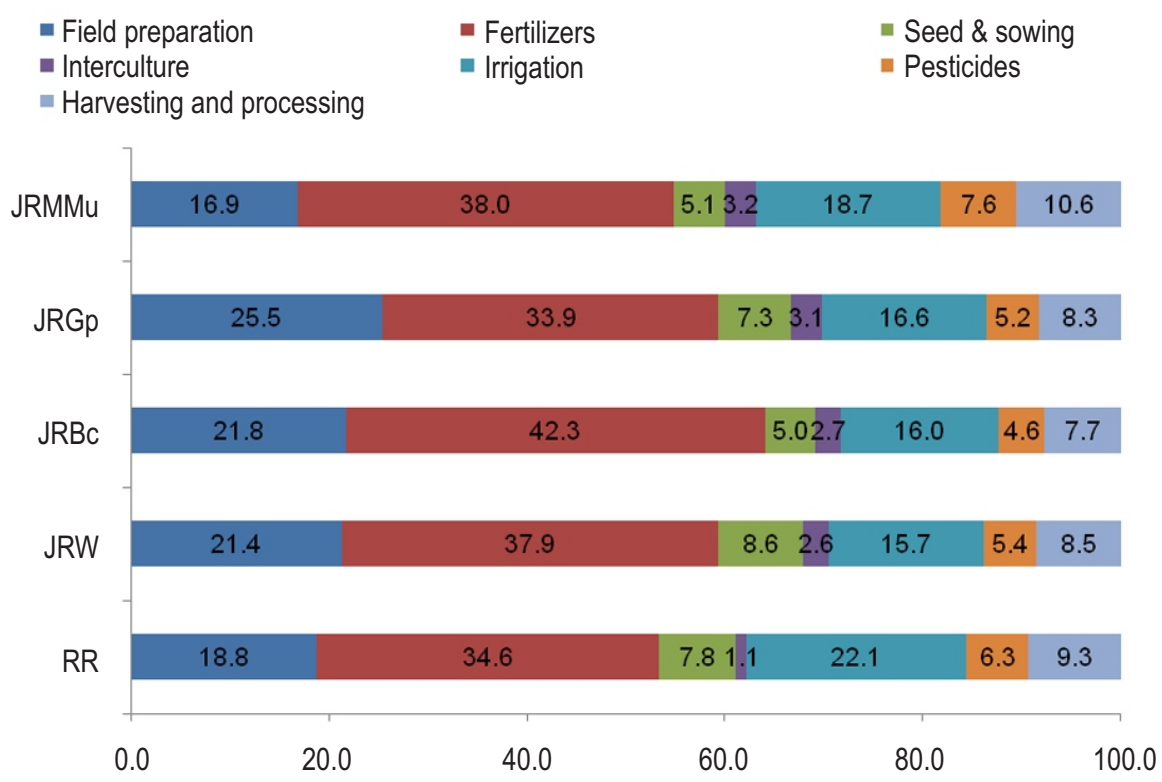

Fig. 2: Field operation wise energy use pattern in different cropping system under RDF: J: Jute; R-Rice; W-Wheat; Gp-Garden pea; Bc-Baby corn; MMustard and Mu-Mungbean.

comparatively higher irrigation for summer/dry season rice. Significant variation in energy output (EO) was recorded among all cropping systems and NCRM practices (Table 1). Significantly $(P<0.05)$ higher EO was recorded in J-R-Bc $\left(370.5 \mathrm{GJ}^{-1}\right)$ compared to other cropping systems. Energy output from J-R-W (355 GJ ha $\left.{ }^{-1}\right)$ and J-R-M-Mu (345.8 GJ ha') was at par but was significantly higher than J-R-Gp (298.9 GJ ha-1). The lowest carbon output (254.3 GJ ha ${ }^{-1}$ ) was recorded with R-R cropping system. Since, EO is function of total biomass (grain+ straw/stalk/sticks+ root) and energy equivalent, biomass production directly influenced the EO. Biomass production varied among the crops, variation in EO, was recorded in different cropping systems. 
Among NCRM practices, significantly $(P<0.05)$ higher energy output (336.9 GJ ha') was recorded with $F_{2} R_{1}$ compared to all other NCRM treatments. Energy output from $F_{1} R_{1}\left(324.7 \mathrm{GJ}\right.$ ha $\left.{ }^{-1}\right)$ and $F_{2} R_{0}\left(324.2 \mathrm{GJ} \mathrm{ha}^{-1}\right)$ was at par but higher in $\mathrm{F}_{1} \mathrm{R}_{0}(313.9 \mathrm{GJ}$ ha $\left.{ }^{1}\right)$. Significantly higher $(P<0.05)$ net energy and total energy use efficiency was recorded in J-R-Bc cropping system compared to others cropping systems. Among NCRM practices significantly higher NE and EUEt was recorded when 75\% NPK applied with crop residues compared to higher dose, i.e., $100 \%$ NPK alone or with crop residues. Energy use efficiency of grain (EUEg) was significantly higher in J-R-M-Mu compared to all other cropping system and it was at par with J-R-Bc and F-R-R cropping systems (Table 1). Among NCRM practices, higher EO and net energy was recorded with $100 \%$ NPK with crop residue, but EUEt, EUEg and EP was highest in 75\% NPK with crop residue. These results indicate that substitution of $25 \%$ NPK/fertilizer with different crop residues, which are non-renewable source of energy, can be enhanced by EUE (Chaudhary et al., 2009; Pratibha et al., 2015; Singh, 2017). Moreover, this will also reduce the burden on inorganic fertilizers which contribute maximum to El major energy input and consumed fossil fuel as well for its production, processing and distributions. Significantly higher energy profitability (Ept) was recorded with J-R-Bc compared to all other systems but it was at par with by J-R-M-Mu cropping system.

Specific energy was significantly higher in J-R-BC cropping system compared to other cropping system. Among NCRM practices significantly higher SE was recorded in $75 \%$ NPK with crop residue compared to others and it was at par with $100 \%$ NPK with crop residue management practices. The average data of three years of different cropping systems for field operation indicated that irrigation practice recorded higher $\mathrm{CO}_{2} \mathrm{e}$ emission (177.4 $\mathrm{kg} \mathrm{Coe} \mathrm{ha}{ }^{-1}$ ) in R-R cropping system while seed bed preparation recorded higher (140.8 $\mathrm{kg} \mathrm{COe} \mathrm{ha}^{-1}$ ) $\mathrm{CO}_{2} \mathrm{e}$ in J-R-W cropping system compared to other remaining cropping system (Table 2). The lowest $\mathrm{CO}_{2} \mathrm{e}$ emission from seed bed preparation (104 kg COe ha ${ }^{-1}$ ) and irrigation practices (76.4 kg COe ha ${ }^{-1}$ ) were in J-R-M-Mu cropping system. $\mathrm{CO}_{2}$ emission of pesticide application (herbicide + insecticide + fungicides) was recorded higher in J-R-M-Mu ( $65.33 \mathrm{~kg}$ COe ha$\left.{ }^{1}\right)$, followed by J-R-W cropping system ( $\left.56.3 \mathrm{~kg} \mathrm{COe} \mathrm{ha-1}\right)$. The highest $\mathrm{CH}_{4}$ based $\mathrm{CO}_{2}$ emission (1139.9 $\mathrm{kg} \mathrm{COe} \mathrm{ha}{ }^{-1}$ ) in R-R cropping system was compared with other cropping systems (Table 2), while, $\mathrm{N}_{2} \mathrm{O}$ based $\mathrm{CO}_{2}$ emission (633.6 kg COe ha ${ }^{-1}$ ) was higher in J-R-M-Mu cropping system.

The R-R (rice-rice) cropping system is known to be exhaustive system in term of utilization of resources like water, nutrient and energy. Rice crop was planted on puddle soil and kept under waterlogged conditions which emits $\mathrm{CH}_{4}$ (Shang et al., 2011). However, in the present study, was practised alternate drying and wetting in R-R system, hence, relatively less $\mathrm{CH}_{4}$ emission was found (Adhya et al., 2000). But, here, two continuous rice crops were grown in R-R cropping system resulted in higher $\mathrm{CH}_{4}$ emission. Jute while retting process also emit $\mathrm{CH}_{4}$ but very negligible amount i.e. $5 \mathrm{~g} \mathrm{CH}_{4} \mathrm{~kg}^{-1}$ fibre has been reported by Palit (2000). The GWP of J-R-M-Mu cropping system was $1775.9 \mathrm{~kg}$ COe ha ${ }^{-1}$ followed R-R cropping system (1677.6 kg COe ha" $\left.{ }^{-1}\right)$.

The highest total GWP was recorded with J-R-M-Mu (4181 kg COe ha $\left.{ }^{-1}\right)$ followed by J-R-W (4176 kg COe ha ${ }^{-1}$ ) and R-R $\left(4161 \mathrm{~kg} \mathrm{COe} \mathrm{ha}^{-1}\right)$ and the lowest in J-R-Gp (3487.9 $\left.\mathrm{kg}^{-} \mathrm{COe} \mathrm{ha}^{-1}\right)$ under $100 \%$ NPK with crop residue incorporation practices. The GWP of all practices was higher in J-R-M-Mu system (which was only $5.5 \%$ higher than R-R double cropping system, though, the former system had four crops in sequence compared to two in later system. The GWP of J-R-M-Mu system was comparatively not too high in spite of four crops in sequence, which required more inputs like, irrigation; pesticides and labours. GWP of R-R system indicated the input intensive system which required high fertilizer, tillage and water. Moreover, in J-R-M-Mu system,

Table 1: Energy use pattern of different cropping systems under nutrient and residue management practices

\begin{tabular}{|c|c|c|c|c|c|c|c|}
\hline Treatments & El (GJ ha') & EO (GJ ha ${ }^{-1}$ ) & NE (GJ ha ${ }^{-1}$ ) & EUEt & EUEg & EP & $S E\left(t G^{-1}\right)$ \\
\hline \multicolumn{8}{|c|}{ Cropping systems (CS) } \\
\hline F-R-R & 38.79 & $254.3^{A}$ & $215.5^{A}$ & $6.56^{A}$ & $3.21^{\mathrm{B}}$ & $5.56^{A}$ & $0.22^{A}$ \\
\hline J-R-W & 47.34 & $355.0^{c}$ & $307.7^{B}$ & $7.52^{\mathrm{B}}$ & $3.04^{B}$ & $6.52^{\mathrm{B}}$ & $0.28^{B}$ \\
\hline J-R-Bc & 46.15 & $370.5^{D}$ & $324.3^{D}$ & $8.04^{c}$ & $3.12^{\mathrm{AB}}$ & $7.04^{c}$ & $0.62^{\mathrm{C}}$ \\
\hline J-R-Gp & 39.68 & $298.9^{B}$ & $259.3^{B}$ & $7.54^{\mathrm{B}}$ & $2.97^{A}$ & $6.54^{\mathrm{B}}$ & $0.42^{B}$ \\
\hline J-R-M-Mu & 43.95 & $345.8^{c}$ & $301.8^{c}$ & $7.88^{\mathrm{B}}$ & $3.24^{\mathrm{B}}$ & $6.88^{\mathrm{C}}$ & $0.35^{\mathrm{B}}$ \\
\hline \multicolumn{8}{|c|}{ Nutrient and crop residue management practices (NCRM) } \\
\hline $\mathrm{F}_{1} \mathrm{R}_{0}$ & 40.89 & $313.9^{\mathrm{a}}$ & $273.0^{\mathrm{a}}$ & $7.64^{\circ}$ & $3.10^{\mathrm{b}}$ & $6.64^{d}$ & $0.37^{\mathrm{a}}$ \\
\hline$F_{1} R_{1}$ & 41.13 & $324.7^{b}$ & $283.6^{\mathrm{b}}$ & $7.87^{\mathrm{d}}$ & $3.26^{c}$ & $6.87^{\circ}$ & $0.39^{b}$ \\
\hline $\mathrm{F}_{2} \mathrm{R}_{0}$ & 45.24 & $324.2^{b}$ & $278.9^{\mathrm{ab}}$ & $7.14^{\mathrm{a}}$ & $3.00^{\mathrm{a}}$ & $6.14^{\mathrm{a}}$ & $0.36^{\mathrm{a}}$ \\
\hline $\mathrm{F}_{2} \mathrm{R}_{1}$ & 45.47 & $336.9^{c}$ & $291.4^{\circ}$ & $7.38^{\mathrm{b}}$ & $3.11^{\mathrm{b}}$ & $6.38^{\mathrm{b}}$ & $0.38^{\mathrm{ab}}$ \\
\hline
\end{tabular}

El- Energy Input, EO- Energy output, NE- Net energy, EUEt- Total energy use efficiency, EUEg- Energy use efficiency (grain), J-Jute; R-Rice; W-Wheat; BcBaby corn; Gp-Gaden pea; M-Mustard and Mu-Mungbean; $F_{1}-75 \%$ NPK; $F_{2}-100 \%$ NPK; $R_{0}-$-No residue; $R_{1}$-Residue incorporation; Means followed by similar letters (Capital letter for main plot and small for sub plot comparision) within a column are not significantly different at $P<0.05$ according to Tukey's HSD test 
Table 2: $\mathrm{CO}_{2}$ equivalent emission from various sources/ practices in different cropping systems

\begin{tabular}{|c|c|c|c|c|c|}
\hline Practices & R-R & J-R-W & $\mathrm{J}-\mathrm{R}-\mathrm{Bc}$ & J-R-Gp & J-R-M-Mu \\
\hline Seed bed preparation and sowing & 123.3 & 140.8 & 119.4 & 134.7 & 104.7 \\
\hline Irrigation (diesel) & 177.4 & 99.3 & 90.4 & 90.4 & 76.3 \\
\hline \multicolumn{6}{|l|}{ Pesticide application } \\
\hline Herbicide & 18.9 & 28.4 & 28.4 & 23.6 & 25.2 \\
\hline insecticide & 7.7 & 11.5 & 10.2 & 7.7 & 15.3 \\
\hline Fungicide & 11.7 & 8.8 & 10.7 & 12.7 & 14.6 \\
\hline Application & 5.1 & 7.6 & 7.6 & 7.6 & 5.1 \\
\hline $\mathrm{CH}_{4}$ based $\mathrm{CO}_{2}$ emission & 1139.9 & 884.9 & 884.9 & 884.9 & 884.9 \\
\hline \multicolumn{6}{|l|}{$\mathrm{N}_{2} \mathrm{O}$ based $\mathrm{CO}_{2}$ emission } \\
\hline Direct & 188.9 & 464.5 & 454.6 & 490.8 & 633.6 \\
\hline Indirect & 4.8 & 11.9 & 11.6 & 12.6 & 16.2 \\
\hline GWP (kg CO $\mathrm{e} \mathrm{ha}^{-1}$ ) & 1677.6 & 1657.6 & 1617.9 & 1665.0 & 1775.9 \\
\hline \multicolumn{6}{|c|}{ Nutrient and crop residue management practices (NCRM) } \\
\hline \multirow[t]{2}{*}{$\mathrm{F}_{1} \mathrm{R}_{0}$} & 1769.1 & 2479.9 & 2308.5 & 1794.1 & 2200.1 \\
\hline & $(3446.7)$ & $(3425.4)$ & $(3216.0)$ & $(2752.3)$ & $(3270.4)$ \\
\hline \multirow[t]{2}{*}{$F_{1} R_{1}$} & 1906.2 & 2788.5 & 2617.0 & 2102.6 & 2508.6 \\
\hline & $(3583.8)$ & $(3596.7)$ & $(3467.6)$ & $(3136.9)$ & $(3698.8)$ \\
\hline \multirow[t]{2}{*}{$\mathrm{F}_{2} \mathrm{R}_{0}$} & 2346.4 & 3291.6 & 3063.0 & 2377.1 & 2914.4 \\
\hline & $(4024.0)$ & $(4004.9)$ & $(3738.5)$ & $(3103.2)$ & $(3752.5)$ \\
\hline \multirow[t]{2}{*}{$\mathrm{F}_{2} \mathrm{R}_{1}$} & 2483.5 & 3600.1 & 3371.5 & 2685.6 & 3222.9 \\
\hline & (4161.1) & (4176.3) & (3989.9) & (3487.9) & $(4181.0)$ \\
\hline
\end{tabular}

J-Jute; R-Rice; W-Wheat; Bc-Baby corn; Gp-Garden pea; M-Mustard and Mu-Mungbean; $F_{1}-75 \%$ NPK; $F_{2}-100 \%$ NPK; $R_{0}$-No residue; $R_{1}$-Residue incorporation; Data in parentheses is total GWP i.e GWP other source + GWP from fertilizer and residue practices

Table 3: Carbon input, carbon output, carbon efficiency (CE) and carbon sustainable index (CSI) of different cropping system and under nutrient and residue management practices

\begin{tabular}{|c|c|c|c|c|}
\hline & C input (kg C ha $\left.{ }^{-1}\right)$ & C output ( $\left.\mathrm{kg} \mathrm{C} \mathrm{ha}^{-1}\right)$ & CE & CSI \\
\hline \multicolumn{5}{|c|}{ Cropping systems (CS) } \\
\hline R-R & 1037.4 & $8371.9^{A}$ & $8.11^{\mathrm{A}}$ & $7.11^{\mathrm{A}}$ \\
\hline J-R-W & 1036.6 & $13358.8^{D}$ & $12.96^{\mathrm{C}}$ & $11.96^{\mathrm{C}}$ \\
\hline J-R-Bc & 982.6 & $14192.0^{\mathrm{E}}$ & $14.51^{\mathrm{D}}$ & $13.51^{\mathrm{D}}$ \\
\hline J-R-Gp & 850.9 & $12298.4^{B}$ & $14.52^{\mathrm{D}}$ & $13.52^{\mathrm{D}}$ \\
\hline J-R-M-Mu & 1016.0 & $12745.1^{\mathrm{C}}$ & $12.61^{\mathrm{B}}$ & $11.61^{\mathrm{B}}$ \\
\hline \multicolumn{5}{|c|}{ Nutrient and crop residue management practices (NCRM) } \\
\hline $\mathrm{F}_{1} \mathrm{R}_{0}$ & 878.8 & $11848.3^{\mathrm{a}}$ & $13.61^{d}$ & $12.61^{d}$ \\
\hline $\mathrm{F}_{1} \mathrm{R}_{1}$ & 953.7 & $12178.5^{b}$ & $12.82^{\circ}$ & $11.82^{c}$ \\
\hline $\mathrm{F}_{2} \mathrm{R}_{0}$ & 1015.8 & $12168.9^{b}$ & $12.13^{b}$ & $11.13^{b}$ \\
\hline $\mathrm{F}_{2} \mathrm{R}_{1}$ & 1090.7 & $12577.4^{\circ}$ & $11.61^{\mathrm{a}}$ & $10.61^{a}$ \\
\hline
\end{tabular}

J-Jute; R-Rice; W-Wheat; Bc-Baby corn; Gp-Garden pea; M-Mustard and Mu-Mungbean; $F_{1}-75 \%$ RDF/NPK; $F_{2}-100 \%$ RDF/NPK; $R_{0}-$ No residue; $R_{1}$ residue incorporation; Means followed by similar letters within a column are not significantly different at $P<0.05$ according to Tukey's HSD test

mustard and mungbean was raised on zero tillage and thereby reduced the emission of $\mathrm{CO}_{2} \mathrm{e}$ by reducing operation time of tractor, machinery and consumption of diesel. Moreover, J-R-MMu system had four crops in sequence cover the soil almost whole year and led to less anthropogenic emission of $\mathrm{N} \mathrm{O}$ and $\mathrm{CO}$ e from the soil (Gan et al., 2014).

Mungbean requires less quantity of nitrogenous fertilizer because it is a leguminous crop that fixes atmospheric nitrogen to fulfill it nitrogen demand. Further, nitrogen content of crop residue (root and fallen leaves and straw) which left over, recycled in the field provides some nutrient to succeeding crop also (Janzen et al., 2003; Gan et al., 2010). The highest total GWP was also recorded with J-R-M-Mu and the lowest in J-R-Gp under 100\% NPK with crop residue incorporation practices. Comparatively lower in J-R-Gp was because, pea in cropping system is legume crop and reason same as stated for mung bean. Among NCRM practices, $100 \%$ NPK with crop residue incorporation 
practices $\left(\mathrm{F}_{2} \mathrm{R}_{1}\right)$ recorded higher $\mathrm{CO}_{2} \mathrm{e}$ emission $(3222.9 \mathrm{~kg}$ COe ha ${ }^{-1}$ ) as compared to other NCRM practices (Table 6). Crop residue increases $\mathrm{CO}_{2}$ emission while it decomposition (Gan et al., 2009; Goglio etal., 2014).

Carbon input and output also varied among different cropping systems and NCRM practices (Table 3 ). Comparatively more carbon input was required for R-R system and less for J-RGp system. Among NCRM practice, carbon input was higher with $F_{2} R_{1}$ as this treatment had comparatively higher quantity of fertilizers and residues than other NCRM practices. Higher carbon input with $F_{2} R_{1}$ due to higher quantity of fertilizers and residues used in this treatment than other NCRM practices. Carbon output was significantly higher in J-R-Bc compared to other cropping system and the lowest carbon output was in R-R system. Among NCRM practices, significantly $(\mathrm{P}<0.05)$ higher carbon output was recorded in $\mathrm{F}_{2} \mathrm{R}_{1}$, however, carbon output in $\mathrm{F}_{1} \mathrm{R}_{1}(75 \%$ $N P K+$ crop residues) and $F_{2} R_{0}(100 \%$ RDF without crop residue) was statistically at par (Table 3). The carbon output is function of total biomass (root+shoots+grain) produced by the crops and cropping system. Since higher biomass was produced in J-R-Bc system this system recorded higher carbon output.

Among NCRM practices, higher carbon output was recorded in $F_{2} R_{1}$, as higher nutrient dose increased the total biomass of crops. The carbon output in $75 \%$ NPK with and without crop residue was statistically at par. This finding indicate that substitution of $25 \%$ nutrient from crop residues increased the carbon output by increasing the crop yield, biomass by improving soil health. Average across years, carbon efficiency (CE) was at par between J-R-Gp (14.52) and J-R-Bc (14.51) cropping systems, but significantly higher than other cropping systems. The lowest $C E$ (8.11) was recorded in $R-R$ cropping system (8.11). Among different NCRM practices, $F_{1} R_{0}$ recorded significantly higher carbon efficiency (13.61) compared to other practices. The lowest $C E$ was recorded with $F_{2} R_{1}$ (11.61). Among different NCRM practices, $F_{1} R_{0}$ recorded higher carbon efficiency and $F_{2} R_{1}$ i.e. $100 \%$ RDF with crop residue recorded lower carbon efficiency. Carbon sustainability index (CSI) recorded significantly higher J-R-Gp (13.52) compared to other systems, butwas at par with both J-R-Bc (13.51).

Among different NCRM practices, $F_{1} R_{0}$ recorded higher CSI (12.61) compared to other practices. This higher CSI and CE were due to higher carbon output with low carbon input. It means that crop residue could not substantially increase the biomass of crops to overcome the carbon input. Higher CE indicates more efficient use of carbon. Carbon footprint is also influenced by different cropping systems and NCRM practices (Fig. 3). Comparatively higher carbon footprint $\left(0.44 \mathrm{~kg} \mathrm{CO}_{2} \mathrm{e} \mathrm{kg}^{-1}\right.$ yield) was recorded with R-R cropping system under all NCRM practices. The lowest carbon footprint $\left(0.28 \mathrm{~kg} \mathrm{CO}_{2} \mathrm{e} \mathrm{kg}{ }^{-1}\right.$ yield) was recorded with J-R-Gp system under all NCRM practices. The lowest carbon foot print $\left(0.27 \mathrm{~kg} \mathrm{CO}_{2} \mathrm{e} \mathrm{kg}^{-1}\right.$ yield) was observed in $75 \%$ NPK without crop residue, while the highest carbon foot print $\left(0.47 \mathrm{~kg} \mathrm{COe} \mathrm{kg}^{-1}\right.$ yield) under $100 \%$ NPK with crop residue incorporation practices (Fig. 3). Among NCRM practices, in general carbon footprint was almost similar ( 0.345 and $0.349 \mathrm{~kg} \mathrm{CO}_{2} \mathrm{e} \mathrm{kg}^{-1}$ yield) in $75 \% \mathrm{NPK}$ with and withoutcrop residue, respectively.

As carbon footprint is a function of economic yield per unit of carbon input used. The input like crop residue emits $\mathrm{CO}_{2}$ while decomposition and increases GWP but unable to substantially increase the economic yield of crops in cropping systems which can nullify the amount of emission. As carbon footprint was calculated on the basis of three years of yield data the carbon footprint was higher in this study. However, in long run adopting

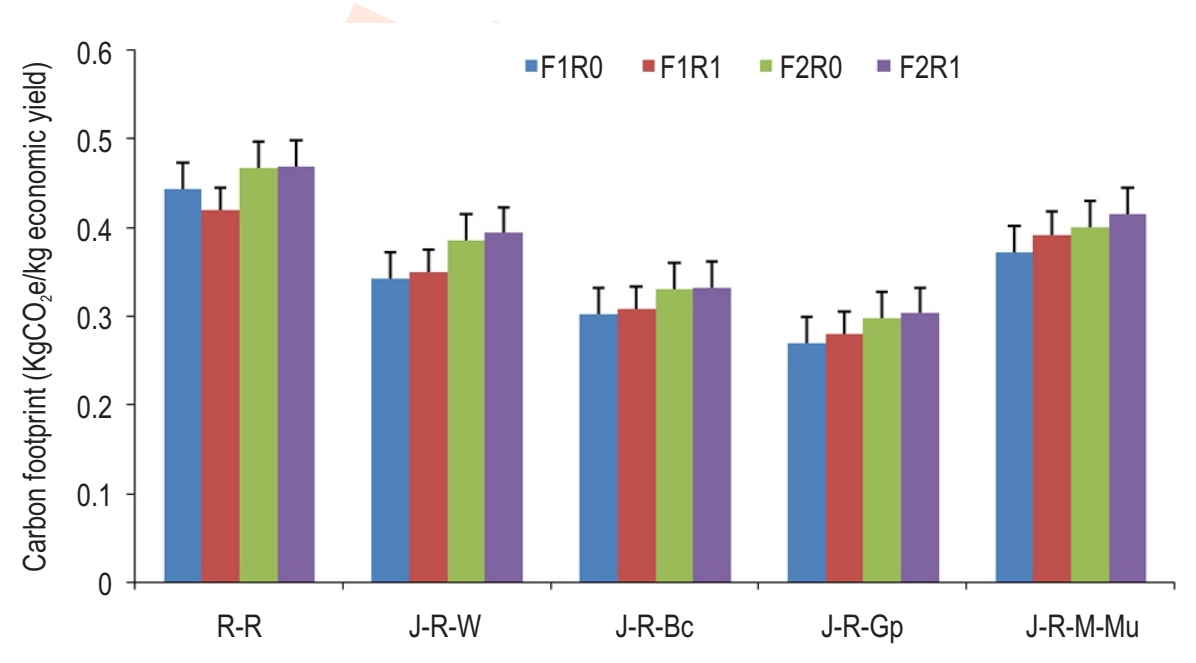

Fig. 3: Carbon foot print of different cropping system under nutrient and crop residue management practices. (J-Jute; R-Rice; W-wheat; Bc-Baby corn; Gp-Garden pea; M-Mustard and Mu-Mungbean; F1-75\% NPK; F2-100\% NPK; R0-No residue; R1-residue incorporation). 
this practices improves soil health and carbon sequestration thereby carbon foot print of cropping system (Lal, 2004; Kumar et al. 2019). Moreover, high rainfall and temperature of this region (eastern Indo-gangetic plain) may not allow to increased carbon content in soil as much as it should have been to substantial increase in economic yield.

From present investigation, it can be conclude that juterice-baby corn (J-R-Bc), jute-rice-garden pea (J-R-Gp) or juterice-mustard-mungbean(J-R-M-Mu) under $75 \%$ NPK with crop residue incorporation in soil can be energy efficient, environmental sustainable and low carbon foot print cropping systems.

\section{Acknowledgment}

The authors are thankful to the Director CRIJAF for initiating this projectand also for their support and encouragement.

\section{Add-on Information}

Authors' contribution: M. Kumar: Developed concept, conducted experiment, calculation of energy, carbon footprint and manuscript writing, S. Mitra: Developed concept and Manuscript editing, A. Bera: Data analysis and manuscript editing, M. R. Naik: Data collection.

Research content: The research content of manuscript is original and has not been published elsewhere.

\section{Ethical approval: NotApplicable}

Conflict of interest: The authors declare that there is no conflict of interest.

\section{Data from other sources: NotApplicable}

Consent to publish: All authors agree to publish the paper in Journal of Environmental Biology.

\section{References}

Adhya, T.K., K. Bharati, S.R. Mohanty, B. Ramakrishnan, V.R. Rao, N. Sethunathan and R. Wassmann: Methane emission from rice fields at Cuttack, India. Nutr. Cycl. Agroecosyst., 58, 95-105 (2000).

Ahmad, R., M. Arshad, M. Naveed, Z.A. Zahir, T. Sultan and M. Khalid: Carbon mineralization rate of composted and raw organic wastes and its implications on environment. Soil Environ., 26, 92-96 (2007).

Bhatia, A., H. Pathak and P.K. Aggarwal: Inventory of methane and nitrous oxide emissions from agricultural soils of India and their global warming potential. Curr. Sci., 87, 317-324 (2004).

Biswas, B., D.C. Ghosh, M.K. Dasgupta, N. Trivedi, J. Timsina and A. Dobermann: Integrated assessment of cropping systems in the Eastern Indo-Gangetic plain. Field Crop Res., 99, 35-47 (2006).

Chaudhary, V.P., B. Gangwar, D.K. Pandey and K.S. Gangwar: Energy auditing of diversified rice-wheat cropping systems in IndoGangetic plains. Energy, 34, 1091-1096 (2009).

Devasenapathy, P., G. Senthilkumar and P.M. Shanmugam: Energy management in crop production. Ind. J. Agron., 54, 80-90 (2009).

Gan Y.T., C. Liang, X.Y. Wang and B.G. Mc Conkey: Lowering carbon footprint of durum wheat through diversifying cropping systems. Field Crops Res., 122,199-206 (2011).

Gan, Y., C. Liang, Q. Chai, R.L. Lemke, C.A. Campbell and R.P. Zenter: Improving farming practices reduces the carbon footprint of spring wheat production. Nat. Commun., 5, 5012 (2014).

Gan, Y., C.A. Campbell, H.H. Janzen, R.L. Lemke, P. Basnyat and C.L. Mc Donald: Nitrogen accumulation in plant tissues and roots and $\mathrm{N}$ mineralization under oilseeds, pulses, and spring wheat. Plant Soil, 332, 451-461 (2010).

Gan, Y.T., C.A. Campbell, H.H. Janzen, R.L. Lemke, P. Basnyat and C.L. Mc Donald: Carbon input to soil from oilseed and pulse crops on the Canadian prairies. Agril Eco. Environ., 132, 290-297 (2009).

Goglio P., B.B. Grant, W.N. Smith, R.L. Desjardins, D.E. Worth, R. Zentner and S.S. Malhi: Impact of management strategies on the global warming potential at the cropping system level. Sci. Total Environ., 490, 921-933 (2014).

IPCC: Intergovernmental Panel on Climate Change, (IPCC) Guidelines for National Greenhouse Gas Inventories. Agriculture, Forestry and other Land Use. Vol. 4. Intergovernmental Panel on Climate Change, Paris, France (2006).

Janzen, H.H., K.A. Beauchemin, Y. Bruinsma, C.A. Campbell, R.L. Desjardins, B.H. Ellert and E.G. Smith: The fate of nitrogen in agroecosystems: An illustrationusing Canadian estimates. Nutr. Cycl. Agroecosyst., 67, 85-102 (2003).

Krupinsky, J.M., K.L. Bailey, M.P. Mc Mullen, B.D. Gossen and T.K. Turkington: Managing plant diseases risk in diversified cropping systems. Agron. J., 94,198-209 (2002).

Kumar, Mukesh, S.R. Singh, S.K. Jha, A. Shamna, S.P. Mazumdar, A. Singh, D.K. Kundu and B.S. Mahapatra: System productivity, profitability and resource use efficiency of jute based cropping systems in the Eastern Indo-Gangetic plain. Ind. J. Agril. Sci., 84, 209-213 (2014).

Kumar N, C.P Nath., K.K. Hazra.,, K, Das, M.S. Venkatesh, M.K. Singh, S.S.Singh, C.S. Praharaj and N.P. Singh: Impact of zero-till residue management and crop diversification with legumes on soil aggregation and carbon sequestration. Soil Tillage. Res., 189,158-167(2019)

Lal, B., P. Gautam, A.K. Nayak, B.B. Panda, P. Bihari, R. Tripathi, M. Shahid, P.K. Guru, D. Chatterjee, U. Kumar and B.P. Meena: Energy and carbon budgeting of tillage for environmentally clean and resilient soil health of rice-maize cropping system. J. Cleaner Prod., 226, 815-830 (2019)

Lal, R.: Carbon emission from farm operations. Environ. Int., 30, 981-990 (2004).

Li, L.J., X.Z. Han, M.Y. You, Y.R. Yuan, X.L. Ding and Y.F. Qiao: Carbon and nitrogen mineralization patterns of two contrasting crop residues in a Mollisol: Effects of residue type and placement in soils. Eur. J. Soil Biol., 54, 1-6 (2012).

Ma, B.L., B.C. Liang, D.K. Biswas, M.J. Morrison and N.B. McLaughlin: The carbon footprint of maize production as affected by nitrogen fertilizer and maize-legume rotations. Nutr. Cycl. Agroecosyst., 94, 15-31 (2012)

Mahapatra, B.S., S. Mitra, K. Mukesh, A.K. Ghorai, S.K. Sarkar, C. Kar, D.K. Kundu, S. Satpathy and P.G. Karmakar: An overview of research and development in jute and allied fibre crops in India. Ind. J. Agron., 57, 72-82 (2012).

Miller, P.R., Y. Gan, B.G. McConkey and C.L. McDonald: Pulse crops in the Northern Great Plains: I Grain productivity and residual effects 
on soil water and nitrogen. Agron. J., 95, 972-979 (2003).

Mittal, J.P. and K.C. Dhawan: Research manual on energy requirements in agricultural sector. New Delhi. ICAR, pp. 150 (1988).

Moreno, M.M., C. Lacasta, R. Meco and C. Moreno: Rainfed crop energy balance of different farming systems and crop rotations in a semiarid environment: Results of a long-term trial. Soil Till.Res., 114, 18-27 (2011).

Palit, P.: Jute retting under natural conditions reduces methane emission. ICAR News, 6, 6 (2000).

Parihar, C.M., S.L. Jat, A.K. Singh, K. Majumdar, M.L. Jat, Y.S. Saharawat, S. Pradhan and B.R. Kuri: Bio-energy, water-use efficiency and economics of maize-wheat-mungbean system under precision-conservation agriculture in semi-arid agroecosystem. Energy, 119, 245-256 (2017).

Pratibha, G., I. Srinivas, K.V. Rao, B.M.K. Raju, C.R. Thyagaraj, G.R. Korwar, B. Venkateswarlu, A.K. Shanker, D. K. Choudhary, K.S. Rao and Ch. Srinivasarao: Impact of conservation agriculture practices on energy use efficiency and global warming potential in rainfedpigeonpea-castor systems. Eur. J Agron., 66, 30-40 (2015).

Rathke, G.W., B.J. Wienhold, W.W. Wilhelm and W. Diepenbrock: Tillage and rotation effect on corn-soybean energy balances in Eastern Nebraska. Soil Till. Res., 97, 60-70 (2007).

Shang, Q., X. Yang, C. Gao, P. Wu, J. Liu and Y. Xu: Net annual global warming potential and greenhouse gas intensity in Chinese double rice-cropping systems: A 3-year field measurement in long-term fertilizer experiments. Global Change Biol., 17, 2196-2210 (2011).

Singh K.P., V. Prakash, K. Srinivas and A.K. Srivastva: Effect of tillage management on energy-use efficiency and economics of soybean (Glycine max) based cropping systems under the rainfed conditions in North-West Himalayan region. Soil Till. Res., 100, $78-$ 82 (2008).

Singh, R.J. and I.P.S. Ahlawat: Energy budgeting and carbon footprint of transgenic cotton-wheat production system through peanut intercropping and FYM addition. Environ. Monit. Assess., 187, $282(2015)$.

Singh, R.J.: Sustainable intensification of transgenic cotton in India - A review. Ind. J. Agrc. Sci., 87, 1267-1276(2017)

Singh, R.J., R.L. Meena, N.K. Sharma, S. Kumar. K. Kumar and D. Kumar: Economics, energy and environmental assessment of diversified crop rotations in sub-Himalayas of India. Environ. Monit. Assess., 188, 79 (2016).

Singh, R.J., J.S. Deshwal, N.K. Sharma, B.N. Ghosh and R. Bhattacharyya: Effects of conservation tillage based agro-geotextiles on resource conservation in sloping croplands of Indian Himalayan region. Soil Till. Res., 191, 37-47 (2019).

Soni, P., C. Taewichit and V.M. Salokhe: Energy consumption and $\mathrm{CO}_{2}$ emissions in rainfed agricultural production systems of Northeast Thailand. Agric. Syst., 116, 25-36 (2013).

Tanaka, D.L., J.M. Krupinsky, S.D. Merrill, M.A Liebig and J.D. Hanson: Dynamic cropping systems for sustainable crop production in the Northern Great Plains. Agron. J., 99, 904-911 (2007).

Timsina, J. and D.J. Connor: Productivity and management of rice-wheat cropping systems: Issues and challenges. Field Crops Res., 69, 93-132(2001).

West, T.O. and G. Marland: A synthesis of carbon sequestration, carbon emissions, and net carbon flux in agriculture: Comparing tillage practices in the United States. Agril. Ecosyt. Environ., 91, 217-232 (2002).

Williams, H. and F. Wikstrom: Environmental impact of packaging and food losses in a life cycle perspective: A comparative analysis of five food items. J. Cleaner Prod., 19, 43-48 (2011).

Zentner, R.P., G.P. Lafond, D.A. Derksen, C.N. Nagy, D.D. Wall and W.E. May: Effects of tillage method and crop rotations on nonrenewable energy use efficiency for a thin Black Chernozem in the Canadian Prairies. Soil Till. Res., 77,125-136 (2004). 